\title{
Entre o bom selvagem e o canibal: representações de índio na literatura infantil brasileira em meados do século $X X$
}

\section{Between the good savage and the cannibal: representations of Amerindians in mid-20 $0^{\text {th }}$ century Brazilian children's literature}

\author{
Iara Tatiana Bonin* \\ Edgar Roberto Kirchof ${ }^{* *}$
}

Resumo: O presente artigo apresenta uma reflexão sobre o modo como são construídas representações de índio nas obras de ficção infantil que circularam de forma expressiva entre 1945-1965, considerado o terceiro período histórico da literatura infantil brasileira. O corpus da análise é composto por seis romances infantis nos quais o índio figura como protagonista ou como importante personagem, a saber: As aventuras de Tibicuera, de Érico Veríssimo (1937); A bandeira das Esmeraldas (1945), de Viriato Corrêa; Expedição aos Martírios (1952) e Volta à Serra Misteriosa (1954), de Francisco Marins; Curumi, o menino selvagem (1956), de Jeronimo Monteiro; Curumim sem nome (1960), de Balthazar de Gadoy Moreira. A partir das análises, concluiu-se que o índio é representado de forma dicotômica nessas obras: de um lado, é um bom selvagem, convertido ao cristianismo, que presta auxílio ao homem branco e está integrado harmonicamente à natureza; de outro lado, é um canibal perigoso e violento, cuja natureza selvagem precisa ser domesticada. As principais referências literárias para a construção dessa dicotomia são buscadas, pelos autores desse período, no cânone da Literatura Brasileira endereçada aos adultos.

Palavras-chave: Literatura infantil. Representação de índios. Indianismo. Estudos Culturais.

Abstract: The representations of Brazilian Indians in Brazilian children fictional
literature during 1945-1965, the third period in the history of Brazilian children's
literature, are discussed. The corpus of current analysis consists of six novels, namely,
As aventuras de Tibicuera, by Érico Veríssimo (1937); A bandeira das Esmeraldas
(1945), by Viriato Corrêa; Expedição aos Martírios (1952) and Volta à Serra Misteriosa
(1954), by Francisco Marins; Curumi, o menino selvagem (1956), by Jeronimo Monteiro;
Curumim sem nome (1960), by Balthazar de Gadoy Moreira, in which the Indian is
the hero or an important character. Results showed that Brazilian Indians were always

*Docente da Universidade Luterana do Brasil. E-mail: <iara.bonin@uol.com.br>

** Docente da Universidade Luterana do Brasil. E-mail: <ekirchof@uol.com.br> 
represented as dichotomous subjects in the above books. On the one hand, Indians are described as "good savages", frequently converted to the Christian faith, harmoniously integrated with nature, and a servant to white people. On the other hand, Indians are also portrayed as dangerous and violent cannibals, whose wild nature must be tamed. The main literary references to the construction of this dichotomy may be found by the authors of the period within the Brazilian literary canon written for adults.

Keywords: Children's literature. Representation of Brazilian Indians. Indianism. Cultural studies.

\section{Introdução}

Pode-se perceber que, desde o século XIX, quando surgiram no Brasil as primeiras obras literárias endereçadas especificamente ao público infantil, as narrativas infantis vêm construindo diferentes representações relativas à identidade dos brasileiros, tanto adultos quanto crianças. Assim as obras infantis, além de serem produções estéticas, também têm construído, ao longo da história, diferentes noções sobre a criança, o adulto, o índio, o negro, o bandeirante, o estrangeiro, a mulher (geralmente mãe ou professora) e tantas outras.

Como destacam Lajolo e Zilberman (1993), de 1890 a 1920 a maior parte das obras sobre crianças publicadas no Brasil seguia o procedimento da adaptação de clássicos consagrados da literatura infantil europeia e universal, como os Contos das Mil e uma noites, o Barão de Münchbausen, Robinson Crusoé, Wilhelm Busch, entre vários outros. Somente a partir de 1920 é que começaram a surgir produções genuinamente nacionais, um de cujos traços característicos iniciais é a presença forte do universo rural no que diz respeito às principais temáticas abordadas. Muitas obras desse período têm um caráter fortemente nacionalista. Além disso, nelas predominam figuras como os netos de Dona Benta - da clássica obra de Monteiro Lobato, O sítio do pica-pau amarelo -, crianças nascidas na cidade que vão passar as férias no sítio ou na fazenda, onde se desenvolvem muitos dos enredos, frequentemente mobilizando figuras míticas do folclore brasileiro.

Em parte, esse fenômeno pode ser explicado pela influência exercida pela própria obra de Monteiro Lobato, visto ter sido Lobato, praticamente, o fundador de uma literatura infanto-juvenil genuinamente nacional. Por outro lado, a valorização do meio rural para representar a nacionalidade brasileira também está atrelada à estrutura socioeconômica que tinha o país naquela época, quando predominava uma configuração eminentemente agrária e regida por elites proprietárias de grandes latifúndios.

Embora tenha trazido alguns elementos novos para a arena das representações, a literatura infantil produzida entre os anos de 1945 a 1965 não foge muito ao lugar-comum do mundo rural. Ainda conforme destacam Lajolo e Zilberman (1993), nesse período o universo rural era marcado por 
duas características recorrentes: de um lado, muitas histórias repetem o topos da fazenda de café que entra em decadência, mas acaba sendo salva pelas crianças protagonistas; de outro, algumas histórias apresentam a fazenda apenas como lugar de lazer ou férias para crianças que vêm da cidade. As autoras afirmam que a principal diferença entre a literatura das décadas anteriores é que o espaço rural, agora, não está mais investido de uma conotação tão nacionalista, característica marcante daquelas décadas, quando a fazenda muitas vezes representava o próprio Brasil.

Essa desvinculação entre o universo agrário e a identidade do país está ligada, entre outras causas, ao avanço da industrialização brasileira, que se faz notar de modo gradativamente mais intenso desde então. Em outros termos, o Brasil se transforma, aos poucos, de um país eminentemente agrário em um país cada vez mais alinhado com o processo industrial - pelo menos em grandes centros, como São Paulo -, e a literatura infanto-juvenil passa a abordar também os problemas e crises inerentes a essa nova configuração socioeconômica. Nesse contexto, Lajolo e Zilberman (1993) também chamam a atenção para a entrada de um novo tipo de personagem no cenário da literatura infantil: o índio. Conforme as autoras, até então eram privilegiados apenas

[...] heróis brancos, não raras vezes, acompanhados de um parceiro subalterno, como ocorre, por exemplo, com João Peralta e Pé-de-Moleque. O índio, porém, está sempre do lado errado, a não ser quando se civiliza, convertendo-se ao cristianismo e aliando-se aos brancos. (LAJOLO; ZILBERMAN, 1993, p. 131).

Considerando, então, o panorama histórico de questões ligadas à representação e à produção de identidades no campo da literatura infantil, o objetivo do presente artigo é discutir o modo como são construídas representações de indio nas obras de ficção infantil que circularam de forma expressiva entre 1945 e 1965, considerado o terceiro período histórico da literatura infantil brasileira. O corpus da análise constitui-se de seis romances infantis nos quais o índio figura como protagonista ou como importante personagem, a saber: $A s$ aventuras de Tibicuera ${ }^{1}$, de Érico Veríssimo (1937); A bandeira das Esmeraldas (1945), de Viriato Corrêa; Expedição aos Martírios (1952) e Volta à Serra Misteriosa (1954), de Francisco Marins; Curumi, o menino selvagem (1956), de Jeronimo Monteiro; Curumim sem nome (1960), de Balthazar de Gadoy Moreira.

Neste trabalho, o conceito de representação é central e se vincula à perspectiva construcionista da linguagem, tal como enunciada, entre outros,

\footnotetext{
${ }^{1}$ Embora a obra As aventuras de Tibicuera tenha sido escrita anteriormente às décadas de 1950 e 1960 , foi selecionada por apresentar as características predominantes das demais obras, além de ter circulado intensamente no circuito de leitura naquele período.
} 
por Stuart Hall (1997). O construcionismo se opõe tanto às teorias que veem a representação como um mero reflexo do mundo real (o significado seria, nesse contexto, uma espécie de reflexo dos próprios objetos, pessoas, ideias ou eventos do mundo real) quanto às que pretendem explicá-lo a partir da intencionalidade do falante. A abordagem construcionista não nega a existência da realidade, mas postula que os significados são construídos a partir de sistemas de representação. Por essa razão, "o significado não é inerente às coisas do mundo. Ele é construído, produzido. É resultado de uma prática de significação.” (HALL, 1997, p. 24).

Não há, desde esta perspectiva, um significado definitivo ou essencialmente verdadeiro, e sim, significados construídos e negociados continuamente. Os sistemas de representação são capazes de definir posições sociais, prescrever ações a partir de regras que estabelecem o que pode ser dito, quando, de que maneira, e quem tem autoridade para fazê-lo. Nessa perspectiva os sentidos são sempre negociados e fixados temporariamente; por isso mesmo ocorrem contínuas lutas pela significação e pela representação, a fim de estabelecer o que conta, aquilo que é considerado válido a respeito das coisas, dos acontecimentos e dos próprios sujeitos.

A análise de narrativas infantis sobre índios na perspectiva construcionista direciona o olhar para a produtividade dessas histórias enquanto representações capazes de instituir significados acerca do que é ser indio. Nesse sentido, a análise de obras infantis que obtiveram expressividade entre 1945 e 1965 permitiu perceber que existem nessas obras representações recorrentes sobre o índio, incorporadas a partir do cânone literário brasileiro destinado a leitores adultos. Tais recorrências apontam a existência de um sistema de representação no qual o índio é retratado dicotomicamente: de um lado, como bom selvagem, e de outro, como canibal.

\section{O bom selvagem}

Nas principais representações produzidas sobre o índio brasileiro e americano, construídas já nos primeiros documentos da era colonial, destaca-se inicialmente a ideia do nativo como um sujeito inocente e dócil por natureza, destituído de religião e de valores como a cobiça, a necessidade de propriedade e de hierarquia. Essa representação se faz presente na Carta de Pero Vaz de Caminha e também pode ser encontrada nos escritos de viajantes portugueses e de outras nacionalidades - tais como os franceses Jean de Léry e André Thevet, por exemplo. A passagem abaixo, retirada da Carta de Caminha, pode ser lida como uma espécie de resumo prototípico dessa representação:

Parece-me gente de tal inocência que, se nós entendêssemos a sua fala e eles a nossa, seriam logo cristãos, visto que não têm nem entendem crença alguma, 
segundo as aparências. E portanto se os degredados que aqui hão de ficar aprenderem bem a sua fala e os entenderem, não duvido que eles, segundo a santa tenção de Vossa Alteza, se farão cristãos e hão de crer na nossa santa fé, à qual praza a Nosso Senhor que os traga, porque certamente esta gente é boa e de bela simplicidade. E imprimir-se-á facilmente neles qualquer cunho que lhe quiserem dar, uma vez que Nosso Senhor lhes deu bons corpos e bons rostos, como a homens bons. E o Ele nos para aqui trazer creio que não foi sem causa. E portanto Vossa Alteza, pois tanto deseja acrescentar a santa fé católica, deve cuidar da salvação deles. E prazerá a Deus que com pouco trabalho seja assim! (CAMINHA, 2002, p. 45).

A partir desse excerto, é possível ler a "inocência" atribuída ao índio no contexto de uma concepção colonialista mais ampla, que reduz o Outro a um significante vazio, sobre o qual pode ser impresso qualquer significado proveniente da cultura do colonizador. Nesse caso interessa, sobretudo, destituir o Outro de todos os valores considerados absolutos e universais pelo próprio colonizador, a saber, sua religião, seu sistema de leis e normas e sua autoridade. A ideia de que os índios não teriam qualquer religião, lei ou autoridade, presente já na Carta de Caminha, tornou-se de fato consagrada pelas formulações de portugueses como Gabriel Soares de Souza e Pero de Magalhães Gândavo, entre outros, algumas décadas mais tarde. Na citação abaixo pode-se ler o modo como Gândavo formulou esse mito no sétimo capítulo de seu Tratado da Terra do Brasil (1570):

Não há, como digo, entre eles, nenhum Rei, nem Justiça, somente em cada aldeia tem um principal que é como capitão, ao qual obedecem por vontade e não por força; morrendo este principal, fica seu filho no mesmo lugar; não serve doutra cousa se não de ir com eles à guerra e aconselhá-los como se hão de haver na peleja, mas não castiga seus erros nem manda sobre eles cousa alguma contra sua vontade. [...] Não adoram cousa alguma e não acreditam que há, na outra vida, glória para os bons e castigo para os maus. Acreditam que tudo se acaba nesta vida e que as almas fenecem com os corpos, e assim vivem bestialmente sem ter conta, nem peso, nem medida. (GÂNDAVO, 1980, p. 124).

As reflexões de Soares de Souza, Gândavo e Caminha, entre outros, forneceram o fundamento para a consolidação de uma representação do ameríndio, já nos primórdios da colonização das Américas, a partir da célebre fórmula "Sem F, sem L e sem R", segundo a qual os nativos não possuiriam fé (F), lei (L) e tampouco religião (R). Embora desperte certa simpatia em alguns viajantes da época, essa característica atribuída ao índio é sumariamente negativa na maioria dos escritos e geralmente é utilizada como argumento para que o índio seja colonizado pelo europeu. 
A representação do índio como um sujeito inocente e desvinculado de instituições como o Estado e a religião recebe uma repaginação importante no século XVIII, a partir das reflexões do filósofo francês Jean-Jacques Rousseau sobre o bom selvagem. Para Rousseau, assim como para outros iluministas, o ameríndio representava uma espécie de "emblema nostálgico da inocência perdida, desfrutando do puro gozo da natureza benfazeja longe de uma civilização malsã". (GOMES, 2007, p. 53). Nesse sentido, diferentemente da perspectiva hegemônica desde o século XVI, segundo o iluminismo de Rousseau, não é mais o índio que deve ser ensinado sobre a religião e a cultura europeia, mas é o próprio europeu que passa agora a aprender, com o índio, como retornar ao seu estado original de "primitivismo redentor". Em outros termos, na perspectiva do iluminismo francês, a velha civilização europeia, já carregada de vícios produzidos pelo distanciamento com relação à natureza e ao estado natural do ser humano - bom em essência - passa a ver, nesse habitante primitivo das selvas, um sujeito ainda não corrompido pelas instituições sociais que pode atuar como uma espécie de exemplo a ser seguido.

A tese iluminista sobre o bom selvagem desempenha um papel fundamental nas representações que a literatura romântica do final do século XVIII e XIX passa a construir sobre o índio, a partir de então. Entretanto, é importante ressaltar que, salvo algumas exceções, as obras literárias daquele período não seguiram à risca a representação rousseauaniana do índio como redentor da civilização, embora a concepção iluminista tenha contribuído para que o índio romântico não apenas fosse incorporado, mas também viesse a desempenhar o papel de herói nacional em muitas narrativas. De modo geral, no Romantismo, o índio, embora sempre exótico e telúrico, é concebido a partir de traços como a bravura, a nobreza, a pureza, tornando-se o símbolo da própria Terra, bem como da Nação Brasileira. Essa transfiguração é possível a partir de uma projeção tão ampla de valores consagrados como ideais na cultura ocidental que o índio se torna uma espécie de construto idealizado do próprio colonizador.

Nas narrativas dos seis livros infantis considerados neste trabalho é reiteradamente resgatada a representação do índio como bom selvagem, tanto na visão hegemônica de sujeito dócil quanto na visão romântica de personagem idealiz̧ado. Geralmente ele incorpora essas identidades quando é cristianizado ou submetido a um projeto de civilização, e assim, numa perspectiva utilitária, passa, de alguma forma, a servir ao colonizador.

Apesar de Érico Veríssimo ser considerado um autor ligado ao Modernismo literário, sua obra infantil As aventuras de Tibicuera está repleta de representações estereotipadas do índio como o bom selvagem que tem prazer em aprender as leis da civilização e religião europeias. A narrativa de Veríssimo conta a história de Tibicuera, um índio tupinambá que nasce antes de 1500 e vive durante 400 anos, 
terminando sua narrativa em um arranha-céu de Copacabana, na cidade do Rio de Janeiro. Essa estratégia de composição permite ao autor revisar vários episódios da história brasileira sob o olhar do protagonista indígena Tibicuera; contudo, ao contrário do que se poderia esperar, esse índio revela um olhar tão eurocêntrico quanto o olhar de qualquer narrador branco, reverenciando o legado civilizatório da cultura europeia e cristã que lhe foi transmitido, principalmente o legado religioso.

Esse aspecto pode ser percebido em vários elementos do livro. Quando estava prestes a ser devorado por um povo indígena rival, por exemplo, Tibicuera é resgatado por ninguém menos do que o próprio Padre Anchieta, um dos principais articuladores das estratégias de conversão do índio à religião católica. Numa atitude de gratidão, Tibicuera se coloca em posição de total subserviência a Anchieta: "Não me lembro de ter dedicado a alguém amizade igual à que dediquei àquele homem. Segui-o por toda a parte como um cão fiel. Sempre estava disposto a sacrificar minha vida por amor dele." (VERÍSSIMO, 2005, p. 52). O uso da palavra "cão", nesse contexto, para se autodenominar, está articulado ao uso reiterado em toda a narrativa de termos como "canibal" e "selvagem" para se referir ao índio como um sujeito que se aproxima do comportamento animal e, assim, é colocado em situação de inferioridade em relação ao europeu.

Também nos livros Expedição aos martírios e Volta à serra misteriosa, que fazem parte de uma trilogia escrita por Francisco Marins, esse mesmo estereótipo é agenciado do início ao fim das histórias, através da relação entre os personagens brancos Tonico e Perova e o personagem índio Pixuíra. Assim como na narrativa de Érico Veríssimo, também aqui o pequeno índio, principal coadjuvante na narrativa, é resgatado pelos protagonistas da barbárie de outros índios, representados pelo vilão Bugre, um índio perverso que se transforma em bandeirante e passa a "caçar" e perseguir índios que ainda vivem nas florestas.

Nos livros de Marins são recorrentes os dois principais estereótipos ligados à representação do bom selvagem: a ideia do índio dócil e completamente dedicado ao branco e a do índio repleto das características idealizadas dos heróis românticos - como bravura e coragem. A primeira característica se apresenta ao longo de todo o enredo, pois, à medida que Tonico e Perova se embrenham em uma expedição pela selva rumo à Serra dos Martírios, o índio Pixuíra os acompanha para servi-los voluntariamente: "Depois, o pobre índio que ele procurou salvar das mãos do Bugre, em reconhecimento, tornou-se seu companheiro inseparável e fora com ele em direção aos Araés" (MARINS, 1966a, p. 83). O fato de os protagonistas seguirem o caminho das antigas bandeiras, de Porto Feliz a Cuiabá, no Estado do Mato Grosso, refirma a grandiosidade do empreendimento colonial e as conquistas dos bandeirantes, estes tidos como personagens centrais neste episódio histórico. 
Ao passo que o índio de Érico Veríssimo vai incorporando completamente a cultura do homem branco ao longo do enredo, o índio de Marins permanece como um eterno coadjuvante:

O indiozinho, sempre bom camarada, a cada vez que encostávamos as canoas para um pouso, internava-se nos campos e voltava trazendo picuás cheios de deliciosas frutas silvestres, que todos comíamos com grande satisfação: marmelo bravo, mangaba, cajus, guabirobas, etc. (MARINS, 1966a, p. 63).

Sua bravura idealizada, por outro lado, é demonstrada nos episódios em que há necessidade de lutar contra inimigos ou quando é submetido por seu próprio povo a provas hercúleas de resistência, das quais sai sempre como um vencedor exímio.

Assim como Pixuíra e Tibicuera, as demais personagens indígenas dos livros infantis desse período representadas sob o signo do bom selvagem são sempre leais aos europeus. É o caso, por exemplo, da índia que acompanha o Bandeirante Fernão Dias, na obra $A$ bandeira das Esmeraldas, e de Curumi, um menino que se une a um grupo de expedicionários, guiando as personagens centrais pelos caminhos da floresta. Também nessas obras, além de dóceis, os índios são revestidos de características idealizadas na estética romântica, tais como bravura, nobreza e altivez.

Por outro lado, tais idealizações românticas, quando projetadas sobre o índio, adquirem matizes diferenciados nos enredos. Nos livros aqui analisados é possível observar duas direções diferentes: de um lado, os índios são integrados ao mundo natural, mas sem oferecer qualquer perigo; de outro lado, aparecem em contextos da vida "civilizada". No primeiro sentido destaca-se, por exemplo, na obra Curumi, o menino selvagem, a exuberância da paisagem e dos elementos naturais, estando o índio integrado a essa paisagem natural. A Amazônia, cenário no qual a trama se desenrola, é representada como uma região de mistérios e de riquezas intermináveis.

Descrevendo, por exemplo, a viagem aérea até a cidade de Belém, o narrador afirma que os aviões "pairam, airosos e bem dispostos, sobre a floresta interminável, como pássaros nativos nas lagoas sombrias da mata" (MONTEIRO, 1956, p. 17); entretanto, a imponente floresta também guarda perigos: as fartas águas escondem piranhas, peixes gigantescos e cobras-grandes; nelas se projetam mitos e histórias sobrenaturais, reconstituídas no desenrolar da narrativa principal. A floresta suscita, desse modo, fascínio e temor. Em outra passagem da narrativa o leitor é informado de que naquela terra

[...] tudo é maravilhoso - o ar transparente, o verde magnífico das árvores, o sorriso das pessoas, a mata virgem onde a cidade encosta [...]. O Brasil está lá - no Norte. O Brasil não é isto, estes monstros de cimento armado e asfal- 
to, de ruídos e gritos, de ranger de dentes e pressa que são as cidades de São Paulo e do Rio. (MONTEIRO, 1956, p. 17).

Observa-se no recorte apresentado um apelo ao "primitivismo redentor", um traço do iluminismo francês destacado anteriormente. A cidade encravada no meio da floresta serve aqui de contraponto às metrópoles, estabelecendo estilos de vida distintos: de um lado, uma relação supostamente harmônica com a natureza, e do outro, uma sociedade carregada de vícios produzidos pelo distanciamento relativo à sua própria natureza.

Sob o exuberante pano de fundo da floresta, o índio figura ora como parte do encantamento suscitado pela paisagem, ora como parte da ameaça que ela significa. Interpretado à luz do código romântico de Rousseau, esse fascínio com a naturalidade, a valentia e a força indígena pode estar ligado à noção de que o índio representaria um "eu” mais autêntico, porque sua imersão na natureza o conecta com algo essencial que, na experiência da cidade, por exemplo, é colocado em segundo plano. Essa representação também pode aludir, por vezes, à noção evolutiva (naturalizada no contexto histórico de meados do século XX) de que o índio representa um "estágio" anterior da civilização, algo como a infância da humanidade.

É Curumi quem conduz e orienta o grupo no interior da densa floresta e os alimenta com caça; ele também serve de intérprete e faz a mediação entre a língua dos colonizadores e a língua caiapó quando os expedicionários capturam um índio e o fazem entregar segredos e tesouros do seu povo. Pela voz de Curumi, o leitor é informado sobre rituais de sacrifício humano, que serão abordados na próxima seção deste texto. Em suma, Curumi é um caso exemplar da representação de bom selvagem articulada à noção de utilidade do índio em um empreendimento colonizador/civilizador.

No livro Curumim sem nome, por sua vez, a história inicia com a descrição da personagem indígena:

Há muitos e muitos anos vivia em São Paulo um indiozinho guarani. Era corajoso, inteligente e vivo como um buscapé. [...]. Na enorme fazenda de Seu Chico Pedroso, onde ele morava, ninguém queria outro moleque para fazer um serviço rápido, levar uma carta, apanhar um animal no pasto e trazê-lo encilhado. (MOREIRA, 1960, p. 7).

A agilidade e presteza do menino são assinaladas em vários momentos na obra, inclusive no enfrentamento aos guaicurus, índios descritos como perigosos, que, por isso mesmo, são posicionados na representação do canibal, destaque que se fará adiante. $\mathrm{O}$ menino consegue fugir, mas é perseguido pelos guaicurus, sendo então salvo por dois bandeirantes paulistas. Em outro momento, quando já havia se afeiçoado aos brancos, o menino salva também a vida de seus 
benfeitores, planejando e executando sozinho uma ação que impede a captura de três protagonistas brancos pelos índios canibais.

A devoção ao colonizador se estabelece, assim, em diferentes momentos nesta história, desde os primeiros contatos com os bandeirantes até a prolongada inserção do jovem índio nas atividades rotineiras da fazenda. A condição servil é justificada, na obra, por meio de afirmações como as seguintes: “[...] quase todos os índios eram bem tratados. Pouco a pouco se habituavam com os costumes dos brancos e nem queriam voltar mais para as tabas"; "tornaram-se os melhores companheiros dos bandeirantes"; "muitos adquiriram instrução, progrediram, e seus filhos e netos, casando-se com brancos, formaram muitas das antigas famílias de boa raça de que descendemos" (MOREIRA, 1960, p. 9).

Também na obra $A$ bandeira das esmeraldas surgem ocasionalmente personagens indígenas envolvidas em uma trama que destaca as "sagas heroicas" dos bandeirantes e, na segunda parte, a "benevolente" ação dos Jesuítas. O seguinte recorte expressa essa ideia:

Nos primeiros tempos, o Brasil era paupérrimo. Ao que se afirmava, havia muita prata, muito ouro e muitas pedras preciosas. Mas, durante um século e pouco, ninguém encontrou essas faladas riquezas. Os bandeirantes paulistas nunca se desiludiram de as encontrar. Tanto e tanto trilharam o sertão à procura das minas de ouro, que acabaram achando uma porção delas. (CORRÊA, 1945, p. 48).

O índio aparece integrado ao trabalho das vilas ou, novamente, acompanhando os bandeirantes e, dessa forma, realizando os mais variados serviços, que abarcam desde funções domésticas até o transporte de carga ou a função de guia pela mata. Um exemplo pode ser destacado: "Uma noite, estava Fernão repousando no interior de sua choça, quando uma índia que ele trouxera de S. Paulo entrou para lhe falar". A narrativa prossegue, informando que ela desejava alertar Fernão Dias de que seu filho e companheiro de viagem estava reunindo homens para rebelar-se contra o pai e trair a "Bandeira". Observa-se, neste recorte, que a condição servil do índio é naturalizada, sendo este representado como leal ao colonizador e, de forma ampla, ao projeto civilizatório colocado em curso. As personagens aderem espontaneamente ou facilmente se acostumam com a condição servil e com a vida considerada "civilizada". Tal aspecto assinala uma característica já discutida neste texto, a saber, que os índios seriam criaturas inocentes e prontas para receber dos europeus os ensinamentos e a religião, servindo a estes em troca de sua suposta benevolência (a civilização seria a dádiva que os índios retribuiriam com sua força física, com seus serviços e com sua lealdade). 
Descreve-se, nessa mesma obra, o trabalho da Companhia de Jesus, enaltecendo o "serviço" prestado ao projeto civilizatório: "ninguém imaginava que a Companhia, quinze anos depois [de criada], viria prestar ao Brasil serviços incomparáveis. Ninguém imaginou que ela viria a ser a maior força civilizadora de nossa terra" (CORRÊA, 1945, p. 101). Na narrativa, subdividida em 14 seções que abordam a ação jesuítica na voz de um avô que ensina ao neto, os jesuítas são caracterizados como "santos", "apóstolos", "capazes dos sacrifícios mais altos a bem da humanidade", e saberiam lidar com uma população de selvagens como era a população do Brasil (CORRÊA, 1945, p. 101).

Por outro lado, a obra destaca que não apenas os índios careciam de assistência e de investimentos civilizatórios:

Logo ao chegar, os Jesuítas compreenderam que não eram unicamente os índios que tinham necessidade de civilização, mas também os próprios europeus que se diziam civilizados. Como vocês sabem, foi com criaturas tiradas das cadeias que as capitanias hereditárias começaram a ser colonizadas [...]. Os selvagens eram ignorantes, mas os europeus, os europeus desenfreados, eram maus. É muito mais fácil orientar para o bem a ignorância, do que guiar a maldade para o bem! (CORRÊEA, 1945, p. 105).

Aqui se expressa, mais uma vez, a noção rousseauniana do bom selvagem, cuja ignorância torna maleável a vontade. Mais uma vez os índios são coadjuvantes, numa trama cujo protagonista é o jesuíta. Índios dóceis compõem essa narrativa e são inseridos nas missões e protegidos pelos padres jesuítas; aprendem ofícios e colaboram para atrair outros indígenas para as missões. Quanto a este último aspecto, a devoção do índio ao colonizador se expressa também sob a forma de traição ao próprio povo indígena (que vive fora das missões) em nome de um ideal civilizatório que se projeta sobre a figura indígena. Em suma, o bom selvagem, neste caso, é bom porque é útil e também por ser entendido como receptivo o bastante para ter sua história, seu corpo, sua cultura reescrita sob a forma de um projeto de nação definido pelo europeu.

\section{O canibal}

Embora no início da colonização, principalmente devido aos escritos de Caminha, Gândavo e Soares, tenha predominado uma visão idealizada do índio - segundo a qual ele habita um paraíso natural, não possui cobiça, governo ou religião -, aos poucos, configura-se uma representação diametralmente oposta à do bom selvagem. À medida que o colonizador europeu descobre alguns rituais religiosos autóctones o mito do selvagem sem religião precisa ser suspenso, e ao mesmo tempo, emergem relatos cada vez mais expressivos do índio enquanto canibal. 
O mito do canibalismo é já iniciado nos Fragmentos do Novo Mundo, por Vespúcio, que logo percebe a existência da prática antropofágica entre os nativos:

E percebemos que eram de um povo que se diz "canibais" e que quase a maior parte desse povo, senão todos, vivem de carne humana. E isto, tenha-o por certo, Vossa Magnificência! Não se comem entre eles, mas viajam em embarcações que se chamam "canoas" e vão trazer presas das ilhas ou terras vizinhas, de um povo inimigo deles ou de um outro povo que não o seu. (VESPUCIO, 2000, p. 5, tradução nossa).

No livro escrito pelo alemão Hans Staden sobre suas viagens ao Brasil, esse tema recebe uma configuração quase romanesca, o que contribuiu para a sua rápida popularização na Europa. O francês Thévet, por sua vez, introduziu um elemento novo nessa questão, quando distinguiu canibal e antropófago: ao passo que o primeiro realmente se alimentaria da espécie humana, o segundo comeria apenas a carne de seus inimigos como uma forma de vingança ou como um tipo de ritual religioso. Com Manuel de Nóbrega, que chega a realizar comparações entre o canibal indígena brasileiro e os canibais africanos citados por Rabelais no quarto livro de Pantagruel, o mito do indígena americano como um canibal acaba se consagrando e entrando definitivamente para o imaginário europeu.

O cânone literário brasileiro direcionado para adultos incorporou desde muito cedo a ideia de que o ameríndio, quando não submetido ao processo civilizatório e cristianizador do europeu, estaria entregue a uma natureza selvagem e animalizada à qual não pode escapar, sendo o canibalismo uma das manifestações dessa natureza. No tocante ao projeto de conquista e colonização, é preciso ressaltar que, da mesma forma como a representação do bom selvagem, também a representação do índio como canibal serve ao propósito colonizador dos europeus, na medida em que propõe, primeiro, que o habitante das Américas se define completamente por sua natureza animal/selvagem e, segundo, que essa natureza só pode ser domesticada através de um modelo civilizatório, dos valores relativos à lei, à religião e à autoridade do próprio europeu.

Esse argumento é construído em vários textos fundadores da literatura brasileira, mas pode ser exemplificado, de modo bastante evidente, pelo modo como um dos representantes da épica árcade, Frei José de Santa Rita Durão, constrói o enredo de Caramuru, em 1722. Logo no primeiro canto o narrador relata, em tom revestido de forte dramaticidade, o ato de canibalismo praticado pelos índios com Sancho, um dos náufragos da expedição de Diogo Álvares Correia:

Correm, depois de crê-lo [morto], ao pasto horrendo,

E, retalhando o corpo em mil pedaços,

Vai cada um famélico trazendo, 
Qual um pé, qual a mão, qual outros os braços:

Outro na crua carne iam comendo,

Tanto na infame gula eram devassos.

Tais há que as assam nos ardentes fossos;

Alguns torrando estão na chama os ossos.

(DURÃO, 2007, Canto I, XVII).

Após representar o índio como um animal faminto que se alimenta gulosamente de carne humana, Santa Rita Durão dá a entender que o europeu tem sua natureza controlada devido à religião cristã - "a fé no Redentor" -, único recurso para domesticar também a essência selvagem do humano:

Que horror da humanidade! ver tragada

Da própria espécie a carne já corrupta!

Quando não deve a Europa abençoada

A fé do Redentor, que humilde escuta?

(DURÃO, 2007, Canto I, XVII-XIX).

Caramuru é um protótipo de narrativa que institui uma separação dicotômica entre o indio selvagem canibal e o indio europeizado e cristianizado, portanto, civilizado, o que serve de argumento e justificativa para o projeto de colonização das novas terras e de exploração de suas riquezas. Essa redenção do índio pela religião cristã ocorre, na narrativa, justamente através do casamento entre Diogo Álvares Correia e a índia Paraguaçu, que se converte ao cristianismo e adota um nome europeu: Catarina.

Nesta direção, também pode ser mencionada uma das obras mais conhecidas do indianismo romântico: $O$ Guarani, escrita por José de Alencar. Nessa obra Peri é um índio guarani que se torna, literal e voluntariamente, escravo de Cecília, a filha de dom Antônio. Destaca-se um recorte da obra no qual o pai de Cecília constata, num momento de enfrentamento com os Aimoré, que a salvação de sua filha está nas mãos de Peri:

D. Antônio, tomando a mão de Peri, disse-lhe com uma voz profunda e solene:

- Se tu fosses cristão, Peri!...

O índio voltou-se extremamente admirado daquelas palavras.

- Por quê?... perguntou ele.

- Por quê?... disse lentamente o fidalgo. Porque, se tu fosses cristão, eu te confiaria a salvação de minha Cecília, e estou convencido de que a levarias ao Rio de Janeiro, à minha irmã.

$\mathrm{O}$ rosto do selvagem iluminou-se; seu peito arquejou de felicidade; seus lábios trêmulos mal podiam articular o turbilhão de palavras que lhe vinham do íntimo da alma. 
- Peri quer ser cristão! exclamou ele.

D. Antônio lançou-lhe um olhar úmido de reconhecimento.

- A nossa religião permite, disse o fidalgo, que na hora extrema todo o homem possa dar o batismo. Nós estamos com o pé sobre o túmulo. Ajoelha, Peri!

O índio caiu aos pés do velho cavalheiro, que impôs-lhe as mãos sobre a cabeça.

- Sê cristão! Dou-te o meu nome.

Peri beijou a cruz da espada que o fidalgo lhe apresentou e ergueu-se altivo e sobranceiro, pronto a afrontar todos os perigos para salvar sua senhora.

- Escuso exigir de ti a promessa de respeitares e defenderes minha filha. Conheço a tua alma nobre, conheço o teu heroísmo e a tua sublime dedicação por Cecília. (ALENCAR, 1996, p. 53-54).

Também se verifica, ao longo do enredo, a construção de um binômio de um lado, os bons selvagens, de quem Peri é o representante mais expressivo, e do outro, os canibais, que neste caso são os Tabajara, mencionados na obra como "bárbaros, horrendos, satânicos, carniceiros, sinistros, horríveis, sedentos de vingança, ferozes” (BOSI, 1992, p. 178).

A representação do índio como um canibal cuja única "reparação" é a conversão à fé cristã adquire forma também nas obras infantis brasileiras produzidas entre 1945 e 1960; no entanto, no contexto específico da literatura infantil essa representação acaba reforçando a distinção existente nas histórias entre aqueles índios descritos como aliados e dóceis (os bons selvagens), a quem se deve acolher, e aqueles descritos como inimigos (os canibais), a quem se deve combater.

É possível perceber a dicotomia entre o índio canibal e o bom selvagem, por exemplo, nos livros de Francisco Marins. Pixuíra, de um lado, é o índio dócil que serve voluntariamente aos seus companheiros em uma expedição à selva, trazendo-lhes alimentos e protegendo-os dos perigos da natureza; os demais índios, de outro lado, são temidos e podem sempre ser canibais. No episódio em que Tonico e Peroba são presos pelos Mutucas, por exemplo, essa representação vem à tona no discurso de Perova: "A gente devia tentar fugir, exclamou Perova. Talvez nos queiram comer assados" (MARINS, 1966b, p. 22).

No livro de Érico Veríssimo, essa dicotomia está presente na biografia do próprio protagonista: antes de conhecer os jesuítas Tibicuera fazia parte de uma tribo regida pela barbárie, marcada pela prática de decapitar os inimigos. O personagem relata do seguinte modo o tratamento dado aos índios da tribo adversária após uma batalha: "Voltamos para a taba com os troféus da vitória. Minha mãe me esperou sorrindo. - Cem cabeças de inimigos. Que lindos enfeites para a nossa caiçara, mãe!” (VERÍSSIMO, 2005, p. 27); mas agora, quando 
se converteu ao cristianismo e mora em uma grande cidade, Tibicuera está completamente integrado à cultura considerada civilizada, o que significa que sua natureza selvagem está domesticada: "Agora, sentado aqui numa boa poltrona, no estúdio de meu apartamento de Copacabana - onde escrevo esta história -, eu sorrio ao me lembrar de meus pensamentos de selvagem". (VERÍSSIMO, 1966 , p. 25).

Ao longo do livro Veríssimo deixa muito claro que a abolição do canibalismo ocorreu através da intervenção dos padres jesuítas, representados pelo próprio Anchieta, que ensinava aos índios regras de civilidade através da religião. Isso se torna evidente na seguinte citação:

Uma das coisas mais admiráveis da história do Brasil foi o trabalho dos jesuítas. Os padres fundaram colégios e, enquanto os outros homens pensavam em arrancar da terra ouro e pedras preciosas, eles se preocupavam exclusivamente com a educação dos selvagens. Achavam que uma alma valia mais que um diamante. E, sem armas de guerra, metiam-se no meio dos índios, aprendiam a sua língua, procuravam mostrar-lhes que eles levavam uma vida feia, sem conhecer o Único Senhor do Universo - Deus, um pai que não gostava que seus filhos na Terra cultivassem o pecado da antropofagia. (VERÍSSIMO, 2005, p. 46).

Em alguns casos, a ligação entre a ideia do canibalismo como decorrência de uma natureza selvagem adquire uma fundamentação evolutiva, de acordo com a qual a civilização é fruto de uma evolução temporal, que vai aperfeiçoando as culturas e os sujeitos. A obra $A$ bandeira das esmeraldas, por exemplo, contém certas passagens em que um ancião se pronuncia e, em uma delas, responde à seguinte indagação, feita pelo neto, Pedrino: "E os índios eram, na verdade, comedores de carne humana?". A resposta do ancião é expressa da seguinte maneira:

Eram [...], mas isso não diminui os índios. Isso não prova que eles tivessem uma alma ignóbil. Mostra apenas que eram atrasados. Só por atraso os indígenas brasileiros usavam a antropofagia. É preciso que nós nos recordemos que eles estavam na idade da pedra polida. (CORRÊEA, 1945, p. 131).

Prosseguindo com sua argumentação, o personagem branco explica que os índios estão mais próximos dos animais do que os europeus, por estarem num estágio inferior de desenvolvimento.

Nas duas primeiras idades - a da pedra lascada e a da pedra polida - o atraso do ser humano é enorme. $\mathrm{Na}$ idade da pedra polida ele vai começando a ter certos sentimentos nobres, mas apenas vai começando. É quase um animal. Está em pleno período de selvageria. Desconhece a piedade humana. É, portanto, natural que ele não saiba quanto é horroroso comer seu semelhante.

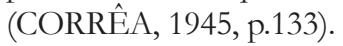


Em outra obra, Curumi, o menino selvagem, o autor chega a estabelecer uma diferenciação em termos de nível evolutivo entre duas tribos diferentes, os açurini e os caiapó:

Os açurinis são terríveis inimigos dos caiapós. São muito valentes, mas não salteadores como os outros. Eles ficam quietos em suas terras, que ocupam à margem direita do Xingu.......] Os açurinis são bons artistas. Fabricam cerâmica, ornamentam seus objetos de uso e suas armas com bom gosto artístico. Tecem redes e dormem nelas. Os caiapós, ao contrário, são rudes, não tecem redes, dormem no chão, não fazem nada de cerâmica e seus objetos de uso são muito rústicos. (MONTEIRO, 1956, p. 51, ortografia atualizada).

Como não poderia deixar de ser, nessa obra a temática do canibalismo está ligada justamente à etnia, representada como "menos evoluída", dos caiapós, o que também reforça a dicotomia entre os índios dóceis (mais evoluídos) e aqueles que constituem um obstáculo a ser eliminado (os canibais não evoluídos): "Eles não deixam os seringueiros trabalhar. Vivem de tocaia na mata e em torno das barracas" (MONTEIRO, 1956, p. 33). O encontro com a personagem que dá nome à obra, Curumi, também marca a distinção entre este e os demais:

Não era, porém, um enorme selvagem tatuado, de aspecto horroroso, mas sim um garoto de 12 ou 13 anos. Estava inteiramente nu [...] a pele estava queimada do sol e os cabelos, também queimados, tinham cor de cobre. [...] Sua fisionomia altiva exprimia decisão e domínio. (MONTEIRO, 1956, p. 63-64).

No capítulo final de Curumi, descreve-se um espaço no qual os caiapó realizam sacrifícios rituais como algo imponente e engenhoso, mas também aterrorizante: "O que vimos foi a prova definitiva de que aquela construção se devia a um povo realmente inteligente e capaz” (MONTEIRO, 1956, p. 137). Apesar dessa menção elogiosa, a descrição que segue dá relevo a outra representação esta, desabonadora. Descendo uma estreita escada de pedras, os protagonistas chegam a um ossuário, situado abaixo de uma ampla mesa ritual - eles comem a carne e os detritos vão para baixo: "esqueletos sem conta amontoavam-se embaixo do buraco circular".

- Que diabo é isso? - berrou Crioulano.

- São os restos dos sacrifícios! - disse eu.

- Que sacrifícios? Isso foi uma mortandade!

- É um costume dos povos primitivos que veio se prolongando até nossos dias nesta região, como estamos vendo. Esses povos antigos costumavam oferecer sacrifícios de sangue aos seus deuses e não era raro que oferecessem também sacrifícios humanos. (MONTEIRO, 1956, p. 137-138).

Outro exemplo dessa dicotomia pode ser visto nas primeiras páginas da obra Curumim sem nome, nas quais se informa que o menino foi aprisionado pelos 
guacuru, inimigos dos guarani. Na maloca destes o menino pressentiu o perigo: "sabia que mais cedo ou mais tarde seria morto. Teria bons alimentos e seria bem tratado, mas isso serviria para engordar depressa e ficar em condições de ser comido" (MOREIRA, 1960, p. 11). Ao final da narrativa são os tamoios que aparecem como desprezíveis e bárbaros, pois teriam aprisionado Curumim e Piaú este último, um menino branco -, para devorá-los, mas são surpreendidos pelos bandeirantes paulistas. "Os salvadores apareceram; eram de fato os paulistas", informa-se no desfecho (MOREIRA, 1960, p. 110), que conseguiram encontrar os meninos graças à astúcia de Piaú, que se oferece para ajudar a pintar corpo dos guerreiros e escreve neles a palavra "socorro". Aqui o binômio civilização-selvageria é representado pela oposição entre a escrita (dominada pelo branco) e a oralidade (forma de comunicação atribuída ao índio).

\section{Considerações finais}

Uma das principais conclusões a que as análises realizadas neste artigo permitem chegar é que, quando o índio passa a ser representado dentro do campo da literatura infantil, a partir da década de 1930, os autores buscam as principais referências para a construção desse personagem no cânone da Literatura Brasileira endereçada aos adultos, no qual o índio já vinha sendo representado, de diversas maneiras, desde o século XVI; mas, curiosamente, os autores da literatura infantil daquele período não buscaram sua inspiração nas obras de seus contemporâneos, que estavam fortemente influenciados pelas concepções do Modernismo.

De fato, vários autores literários identificados com a estética modernista já vinham desconstruindo, em seus romances, o pensamento colonialista e eurocêntrico em torno do índio e de outras etnias já desde a década de 20. Nesse contexto, deve ser mencionada a obra Macunaíma, de Mário de Andrade, como um marco da revisão de representações literárias consagradas sobre o índio e o negro no cânone literário tradicional. A tendência iniciada com Mario de Andrade e o Modernismo teve uma grande repercussão quanto ao modo como o índio passou a ser representado a partir de então. Como esclarece Rubelise da Cunha (2007, p. 336), ao invés de rememorar antigas concepções eurocêntricas sobre o índio, nas quais ele se define como um Outro na relação com o europeu, autores como, por exemplo, Antônio Callado em Quarup (1967), e Darcy Ribeiro em Maíra (1976), passaram a apontar as incoerências do discurso eurocêntrico sobre esse sujeito.

Não obstante, a literatura infantil produzida entre 1945 e 1960 não se alinhou com o projeto ético-estético do Modernismo brasileiro; antes, procurou as principais referências para a construção do personagem indígena justamente em 
uma antiga dicotomia existente já desde o início do cânone literário brasileiro, a saber, a ideia do índio enquanto simultaneamente bom selvagem e canibal. Instituída já nos textos dos primeiros exploradores das Américas, essa representação dicotômica foi sendo reproduzida à exaustão ao longo da história da literatura brasileira, chegando a se transformar em um verdadeiro estereótipo, o qual foi amplamente incorporado pelas narrativas infantis produzidas no Brasil entre as décadas de 1945 e 1960.

\section{Referências}

ALENCAR, J. de. Guarani. 20. ed. São Paulo: Ática, 1996.

BOSI, A. Dialética da colonização. 3. ed. São Paulo: Companhia das Letras, 1992.

CAMINHA, P. V. Carta a El Rei D. Manuel. 3. ed. Porto Alegre: Mercado Aberto, 2002. CORRÊA, V. A bandeira das Esmeraldas. São Paulo: Nacional, 1945.

CUNHA, R. Índio. In: BERND, Z. (Org.). Dicionário de figuras e mitos literários das Américas. Porto Alegre: Tomo Editorial/ Editora da Universidade, 2007. p. 335-339.

DURÃO, S. R. Caramuru. São Paulo: Martin Claret, 2007.

GÂNDAVO, P. de M. Tratado da Terra do Brasil. Belo Horizonte: Itatiaia, 1980.

GOMES, H. T. Bom selvagem. In: BERND, Z. (Org.). Dicionário de figuras e mitos literários das Américas. Porto Alegre: Tomo Editorial/ Editora da Universidade, 2007. p. 52-57.

HALL, S. Representation, cultural representations and signifying practices. London: Thousands Oaks; New Delhi: Sage, 1997.

LAJOLO, M.; ZILBERMAN, R. Um Brasil para crianças - para conhecer a literatura infantil brasileira: histórias, autores e textos. 4. ed. São Paulo: Global, 1993.

MARINS, F. Expedição aos Martírios. São Paulo: Melhoramentos, 1966a.

Volta à Serra Misteriosa. São Paulo: Melhoramentos, 1966b.

MONTEIRO, J. Curumi, o menino selvagem. São Paulo: Brasiliense, 1956.

MOREIRA, B. Curumim sem nome. São Paulo: Editora do Brasil, 1960.

VERÍSSIMO, E. As aventuras de Tibicuera. São Paulo: Companhia das Letras, 2005.

VESPUCIO, A. Fragmentos del Nuevo Mundo. 2000. p. 1-17. Disponível em <http:// www.dominiopublico.gov.br/download/texto/bk000343.pdf>. Acesso em: 24 fev. 2013.

Recebido em 31/05/2012

Versão final recebida em 20/08/2012

Aceito em 19/11/2012 